\title{
Long term effect of a school based antismoking programme
}

\author{
M MURRAY, A V SWAN, AND G CLARKE \\ From the Department of Community Medicine, United Medical and Dental Schools of Guy's and St Thomas's \\ Hospitals, St Thomas's Hospital Medical School, London SE1 7EH, UK
}

SUMMARY In the winters of 1977-8 and 1978-9 about 400 children in seven junior schools in northern England were taught the "My Body" health education programme. In the springs of 1980 and of 1982 these children, and an age matched control group, answered a questionnaire about their smoking behaviour, knowledge, and attitudes. Comparison of the two groups sugggested that the programme had had a positive effect on the boys but a negligible, or even negative, effect on the girls. Various suggestions as to the reasons for this differential impact are discussed.

The health hazards of smoking are now well established. ${ }^{1}$ Despite this a large proportion of the population continues to smoke. Recent antismoking campaigns have concentrated on persuading children not to adopt the habit. It is reasoned that if children can be dissuaded from smoking then eventually a whole non-smoking generation can be produced. These efforts, however, have not been very successful.

In the mid-1970s the Health Education Council (HEC) in conjunction with the City of Sheffield Education Department developed a modification of the School Health Curriculum Project which apparently had had some success in persuading American children not to smoke. ${ }^{2}$ The version developed for use in British schools is known as the HEC "My Body" project.

Initial evaluation of the effectiveness of this My Body project suggested that it had a beneficial effect on the knowledge, attitudes, and, to a lesser extent, smoking behaviour of a sample of schoolchildren. ${ }^{34}$ We report a longer term evaluation of the impact of the project.

\section{Method}

In the winter of 1977-8 the first part of the My Body project (the lung unit) was taught to the 9-10 year old pupils in seven junior schools in Sheffield and Derbyshire. The next winter the same children, then aged 10-11 years, in six out of the original seven junior schools were taught the second part of the project (the heart unit). In the autumn of 1979 most of the children who attended these seven junior schools moved on to three secondary schools in the area, where they were mixed with children who had attended other junior schools.

In the spring of 1980 all the 11-12 year old pupils in the three secondary schools $(n=683)$ were approached to answer a questionnaire about their smoking behaviour, health knowledge, and attitudes. Of the 631 children who answered the questionnaire ( $92 \%$ response rate), 614 had answered the questions on smoking. Two years later all the 13-14 year olds in the three schools were given an identical questionnaire. Of the 614 children who had answered the questionnaire fully in 1980, 533 answered it again in 1982, giving a tracing rate of $87 \%$.

This study design enabled us to contrast the smoking behaviour, knowledge, and attitudes of a group of children who had been taught the My Body project with an age matched control group of children one year and three years after the project had ended. Unfortunately, the control group was not approached until 1979. Thus although they came from similar backgrounds, we cannot be entirely confident that the two groups of children were comparable with respect to smoking behaviour, knowledge, and attitudes before the project began. None the less there is no particular reason to believe that they were not.

A series of analyses were conducted in which the children's replies to the questions about smoking, health knowledge, and attitudes, dichotomised as negative or positive, were taken in turn as response 
variables in a linear model, ${ }^{5}$ along with details of whether or not the children had been taught the project, their sex, parents' social class, and parents' and siblings' smoking behaviour. This allowed us to estimate the relationship between participation in the My Body project and the children's replies to the different questions while controlling for the effects of the other variables. For the longitudinal analyses incidence of smoking among non-smokers was used as the response variable. In addition, for the parents' changes in smoking behaviour, which could change in either direction a linear model version of McNemar's test $^{6}$ was used to assess differences between the parents of children in the two treatment groups. Results have been classified as significant if they reached the $5 \%$ significance level $(p<0 \cdot 05)$.

\section{Results}

Table 1 gives the children's self reported smoking behaviour in 1980 and 1982 according to their replies to three separate questions. The boys in the intervention group, who had been taught the My Body project, were less likely than the control group of boys to have "ever smoked," to "smoke regularly," or "intend to smoke." In both years, however, more girls in the intervention group than in the control group had smoked at least one cigarette or smoked regularly. Admittedly in 1980 fewer of the girls in the intervention than in the control group intended to smoke but two years later this position was reversed.

Table 2 shows the incidence of smoking between 1980 and 1982 . A slightly smaller proportion of boys in the intervention group than in the control group tried smoking for the first time, became regular smokers, or developed the intention to smoke when older between 1980 and 1982. Among girls this pattern was reversed with the incidence of smoking being consistently higher in the intervention group. In addition, within the intervention group more girls than boys began smoking regularly between 1980 and 1982 whereas in the control group it was the reverse. Individually, these effects were not significant, but the differences in the pattern seen for the boys and that seen for the girls was detected as significant in the linear model.

Table 3 gives the smoking practices of the children's parents and siblings as reported by the children. The overall prevalence of parents smoking was slightly lower in the intervention group and the general decline between 1980 and 1982 was slightly more apparent in that group. The smoking behaviour of siblings which increased significantly between 1980 and $1982(p<0 \cdot 01)$ differed between the sexes and the treatment groups. Among the boys the intervention group had a lower proportion of

Table 1 Smoking behaviour of the children in 1980 and 1982

\begin{tabular}{|c|c|c|c|c|c|}
\hline & & \multicolumn{2}{|c|}{$\begin{array}{l}1980 \\
\text { (11-12 year olds) }\end{array}$} & \multicolumn{2}{|c|}{$\begin{array}{l}1982 \\
\text { (13-14 year olds) }\end{array}$} \\
\hline & & Control & Intervention & Control & Intervention \\
\hline Ever smoked & $\begin{array}{l}\text { Boys } \\
\text { Girls }\end{array}$ & $\begin{array}{l}40 \% \\
22 \%\end{array}$ & $\begin{array}{l}34 \% \\
32 \%\end{array}$ & $\begin{array}{l}58 \% \\
50 \%\end{array}$ & $\begin{array}{l}53 \% \\
59 \%\end{array}$ \\
\hline $\begin{array}{l}\text { Smoked regularly } \\
(\geqslant 1 \text { cigarette/week })\end{array}$ & $\begin{array}{l}\text { Boys } \\
\text { Girls }\end{array}$ & $\begin{array}{l}6 \% \\
1 \%\end{array}$ & $\begin{array}{l}2 \% \\
2 \%\end{array}$ & $\begin{array}{r}14 \% \\
9 \%\end{array}$ & $\begin{array}{r}7 \% \\
16 \%\end{array}$ \\
\hline Intend to smoke & $\begin{array}{l}\text { Boys } \\
\text { Girls }\end{array}$ & $\begin{array}{l}11 \% \\
10 \%\end{array}$ & $\begin{array}{l}4 \% \\
7 \%\end{array}$ & $\begin{array}{l}17 \% \\
13 \%\end{array}$ & $\begin{array}{r}9 \% \\
18 \%\end{array}$ \\
\hline No (max) & $\begin{array}{l}\text { Boys } \\
\text { Girls }\end{array}$ & $\begin{array}{r}112 \\
87\end{array}$ & $\begin{array}{l}177 \\
157\end{array}$ & $\begin{array}{r}112 \\
87\end{array}$ & $\begin{array}{l}177 \\
157\end{array}$ \\
\hline
\end{tabular}

Table 2 Change in children's smoking behaviour between 1980 and 1982

\begin{tabular}{|c|c|c|c|c|c|}
\hline & & \multicolumn{2}{|c|}{ Control } & \multicolumn{2}{|c|}{ Intervention } \\
\hline & & $\%$ & No & $\%$ & No \\
\hline $\begin{array}{l}\text { New experimental smokers }(\text { No }=\text { non-smokers } \\
\text { in 1980) }\end{array}$ & $\begin{array}{l}\text { Boys } \\
\text { Girls }\end{array}$ & $\begin{array}{l}37 \% \\
39 \%\end{array}$ & $\begin{array}{l}(62) \\
(66)\end{array}$ & $\begin{array}{l}36 \% \\
42 \%\end{array}$ & $\begin{array}{l}(115) \\
(104)\end{array}$ \\
\hline $\begin{array}{l}\text { New regular smokers }(\text { No = non-regular smokers } \\
\text { in 1980) }\end{array}$ & $\begin{array}{l}\text { Boys } \\
\text { Girls }\end{array}$ & $\begin{array}{r}11 \% \\
7 \%\end{array}$ & $\begin{array}{l}(99) \\
(84)\end{array}$ & $\begin{array}{r}6 \% \\
15 \%\end{array}$ & $\begin{array}{l}(168) \\
(151)\end{array}$ \\
\hline $\begin{array}{l}\text { New future smokers }(\text { No }=\text { did not intend to smoke } \\
\text { in 1980) }\end{array}$ & $\begin{array}{l}\text { Boys } \\
\text { Girls }\end{array}$ & $\begin{array}{r}10 \% \\
8 \%\end{array}$ & $\begin{array}{r}(100) \\
(78)\end{array}$ & $\begin{array}{r}7 \% \\
14 \%\end{array}$ & $\begin{array}{l}(168) \\
(141)\end{array}$ \\
\hline
\end{tabular}


Table 3 Smoking behaviour of children's families in 1980 and 1982

\begin{tabular}{|c|c|c|c|c|c|c|c|c|c|}
\hline \multirow[b]{3}{*}{$\begin{array}{l}\text { At least one parent smokes } \\
\text { (No = children with both parents) }\end{array}$} & \multirow[b]{3}{*}{$\begin{array}{l}\text { Boys } \\
\text { Girls }\end{array}$} & \multicolumn{4}{|c|}{$\begin{array}{l}1980 \\
\text { (11-12 years olds) }\end{array}$} & \multicolumn{4}{|c|}{$\begin{array}{l}1982 \\
(13-14 \text { year olds })\end{array}$} \\
\hline & & \multicolumn{2}{|c|}{ Control } & \multicolumn{2}{|c|}{ Intervention } & \multicolumn{2}{|c|}{ Control } & \multicolumn{2}{|c|}{ Intervention } \\
\hline & & $\begin{array}{l}53 \% \\
50 \%\end{array}$ & $\begin{array}{r}(104) \\
(82)\end{array}$ & $\begin{array}{l}46 \% \\
51 \%\end{array}$ & $\begin{array}{l}(167) \\
(154)\end{array}$ & $\begin{array}{l}50 \% \\
41 \%\end{array}$ & $\begin{array}{r}(104) \\
(82)\end{array}$ & $\begin{array}{l}39 \% \\
42 \%\end{array}$ & $\begin{array}{l}(167) \\
(154)\end{array}$ \\
\hline $\begin{array}{l}\text { At least one sibling smokes } \\
\text { (No = children with siblings) }\end{array}$ & $\begin{array}{l}\text { Boys } \\
\text { Girls }\end{array}$ & $\begin{array}{r}17 \% \\
5 \%\end{array}$ & $\begin{array}{r}(106) \\
(83)\end{array}$ & $\begin{array}{l}7 \% \\
8 \%\end{array}$ & $\begin{array}{l}(158) \\
(142)\end{array}$ & $\begin{array}{l}23 \% \\
13 \%\end{array}$ & $\begin{array}{r}(106) \\
(83)\end{array}$ & $\begin{array}{l}13 \% \\
23 \%\end{array}$ & $\begin{array}{l}(158) \\
(142)\end{array}$ \\
\hline
\end{tabular}

smoking siblings than the control group, significantly so in 1980. Among the girls the reverse was the case, although the differences did not reach significance.

Table 4 shows that a higher proportion of the parents of the girls than of the boys stopped smoking between 1980 and 1982 . Of those parents changing their smoking behaviour, the proportion giving up was consistently greater $(0.05<\mathrm{p}<0.1)$ among the parents of the intervention group than among those of the control group. Similarly there were more children reporting siblings giving up in the intervention group than in the control group but only 45 children overall had smoking siblings in 1980 so the numbers are very small.

Table 5 summarises the health knowledge, attitudes, extent of family problems, and presence of an antismoking norm in the replies of the two groups of children in 1980 and 1982 . Each of these measures was derived from the children's replies to a series of questions detailed in a previous paper. ${ }^{4}$

In both years more children in the intervention group than in the control group were aware of the various health hazards caused by smoking listed in a "smoking quiz" developed by Engel (E Engel, unpublished data). The difference between the groups, however, decreased slightly between 1980 and 1982 and was significant only in 1980 . The intervention group of children were also better able to identify from a list of ten diseases the five caused by smoking. The differences were all significant except for the girls in 1982. Between 1980 and 1982 there was a general increase in the children's awareness of the health hazards of smoking. This increase was less among girls than among boys and least among the girls in the intervention group. Similarly, although there was a slight increase between 1980 and 1982 in the proportion of the control children who could identify the diseases caused by smoking, there was a small decrease among the intervention children.

In their attitudes to smoking there was little difference between the intervention and control boys but among the girls slightly more of those in the intervention than in the control group held antismoking attitudes. Between 1980 and 1982 the proportion of children holding anti-smoking attitudes declined significantly $(p<0.05)$. This decline was slightly greater among girls than among boys.

Significantly more $(p<0.05)$ children in the intervention than in the control group had only "a few" problems at home. The number of problems reported by the children varied little between 1980 and 1982.

The children in the intervention group were also significantly more $(p<0.05)$ likely than those in the control group to report an antismoking norm at home or with friends. Between 1980 and 1982 there was a general decline in the proportion reporting an antismoking norm, especially among the intervention group of children. This decline was greatest among the intervention group of girls.

Table 4 Change in smoking behaviour of parents and siblings between 1980 and 1982

\begin{tabular}{|c|c|c|c|c|c|}
\hline & & \multicolumn{2}{|c|}{ Control } & \multicolumn{2}{|c|}{ Intervention } \\
\hline & & $\%$ & (No) & $\%$ & (No) \\
\hline $\begin{array}{l}\text { Parents who take up smoking (No = parents non-smokers } \\
\text { in 1980) }\end{array}$ & $\begin{array}{l}\text { Boys } \\
\text { Girls }\end{array}$ & $\begin{array}{r}10 \% \\
7 \%\end{array}$ & $\begin{array}{l}(49) \\
(41)\end{array}$ & $\begin{array}{l}4 \% \\
8 \%\end{array}$ & $\begin{array}{l}(91) \\
(75)\end{array}$ \\
\hline $\begin{array}{l}\text { Parents who give up smoking (No = parents smokers } \\
\text { in 1980) }\end{array}$ & $\begin{array}{l}\text { Boys } \\
\text { Girls }\end{array}$ & $\begin{array}{l}15 \% \\
24 \%\end{array}$ & $\begin{array}{l}(58) \\
(41)\end{array}$ & $\begin{array}{l}20 \% \\
27 \%\end{array}$ & $\begin{array}{l}(76) \\
(79)\end{array}$ \\
\hline $\begin{array}{l}\text { Siblings who take up smoking (No = sibling non-smokers } \\
\text { in 1980) }\end{array}$ & $\begin{array}{l}\text { Boys } \\
\text { Girls }\end{array}$ & $\begin{array}{l}11 \% \\
10 \%\end{array}$ & $\begin{array}{l}(88) \\
(79)\end{array}$ & $\begin{array}{l}10 \% \\
18 \%\end{array}$ & $\begin{array}{l}(147) \\
(130)\end{array}$ \\
\hline $\begin{array}{l}\text { Siblings who give up smoking (No = siblings smokers } \\
\text { in 1980) }\end{array}$ & $\begin{array}{l}\text { Boys } \\
\text { Girls }\end{array}$ & $\begin{array}{l}22 \% \\
25 \%\end{array}$ & $\begin{array}{r}(18) \\
(4)\end{array}$ & $\begin{array}{l}36 \% \\
33 \%\end{array}$ & $\begin{array}{l}(11) \\
(12)\end{array}$ \\
\hline
\end{tabular}


Table 5 Health knowledge, attitudes, extent of family problems, and presence of antismoking norm in the two groups of children

\begin{tabular}{|c|c|c|c|c|c|}
\hline & & \multicolumn{2}{|c|}{$\begin{array}{l}1980 \\
\text { (11-12 year olds) }\end{array}$} & \multicolumn{2}{|c|}{$\begin{array}{l}1982 \\
\text { (13-14 year olds) }\end{array}$} \\
\hline & & Control & Intervention & Control & Intervention \\
\hline $\begin{array}{l}\text { Aware of all } \\
\text { health hazards }\end{array}$ & $\begin{array}{l}\text { Boys } \\
\text { Girls }\end{array}$ & $\begin{array}{l}22 \% \\
28 \%\end{array}$ & $\begin{array}{l}36 \% \\
43 \%\end{array}$ & $\begin{array}{l}42 \% \\
38 \%\end{array}$ & $\begin{array}{l}53 \% \\
45 \%\end{array}$ \\
\hline $\begin{array}{l}\text { Able to identify } \\
\text { diseases }\end{array}$ & $\begin{array}{l}\text { Boys } \\
\text { Girls }\end{array}$ & $\begin{array}{l}18 \% \\
17 \%\end{array}$ & $\begin{array}{l}36 \% \\
43 \%\end{array}$ & $\begin{array}{l}19 \% \\
25 \%\end{array}$ & $\begin{array}{l}31 \% \\
27 \%\end{array}$ \\
\hline $\begin{array}{l}\text { Antismoking } \\
\text { attitude }\end{array}$ & $\begin{array}{l}\text { Boys } \\
\text { Girls }\end{array}$ & $\begin{array}{l}78 \% \\
74 \%\end{array}$ & $\begin{array}{l}78 \% \\
82 \%\end{array}$ & $\begin{array}{l}51 \% \\
45 \%\end{array}$ & $\begin{array}{l}54 \% \\
52 \%\end{array}$ \\
\hline $\begin{array}{l}\text { Few problems } \\
\text { at home }\end{array}$ & $\begin{array}{l}\text { Boys } \\
\text { Girls }\end{array}$ & $\begin{array}{l}34 \% \\
30 \%\end{array}$ & $\begin{array}{l}53 \% \\
54 \%\end{array}$ & $\begin{array}{l}31 \% \\
29 \%\end{array}$ & $\begin{array}{l}53 \% \\
49 \%\end{array}$ \\
\hline $\begin{array}{l}\text { Anti smoking } \\
\text { norm }\end{array}$ & $\begin{array}{l}\text { Boys } \\
\text { Girls }\end{array}$ & $\begin{array}{l}29 \% \\
25 \%\end{array}$ & $\begin{array}{l}53 \% \\
49 \%\end{array}$ & $\begin{array}{l}25 \% \\
20 \%\end{array}$ & $\begin{array}{l}38 \% \\
29 \%\end{array}$ \\
\hline No (max) & $\begin{array}{l}\text { Boys } \\
\text { Girls }\end{array}$ & $\begin{array}{r}112 \\
87\end{array}$ & $\begin{array}{l}177 \\
157\end{array}$ & $\begin{array}{r}112 \\
87\end{array}$ & $\begin{array}{l}177 \\
157\end{array}$ \\
\hline
\end{tabular}

The linkage of the data collected in 1980 and 1982 enabled a longitudinal analysis to consider the relative importance of the various 1980 characteristics in predicting the uptake of smoking among children in the following two years. Table 6 gives the incidences of regular smoking between 1980 and 1982 in children not smoking regularly in 1980 by a number of different factors.

This shows that among boys the risk of adopting smoking between 1980 and 1982-that is, between 11 and 14 years - was greater if in 1980 they had not participated in the My Body project, had siblings who smoked, had tried smoking or intended to smoke, had many family problems, reported the presence of a prosmoking norm, and were unable to identify the diseases caused by smoking. In a regression analysis which considered all these variables together the relation with intention to smoke reached statistical significance $(p<0.05)$ and that with sibling smoking behaviour almost reached significance $(\mathrm{p}<0 \cdot 1)$.

Among girls the risk of adopting smoking between 1980 and 1982 was greater if in 1980 they had participated in the My Body project, came from manual households, had siblings who did not smoke, reported a prosmoking norm, were aware of the health hazards of smoking, and held a prosmoking attitude. In the regression analyses the relation with experimental smoking in 1980 reached significance $(p<0.05)$ and those with social class, awareness of health hazards, and attitude to smoking almost reached significance $(p<0 \cdot 1)$.

\section{Discussion}

The results of this long term evaluation of the My Body project agree more or less with those of the short term evaluation. ${ }^{4}$ Boys who were taught theo programme were less likely than other boys to smoked subsequently. It appeared, however, that girls who were taught the programme were more likely than other girls to adopt smoking subsequently.

The pattern of sibling smoking (table 3) parallels this in that the control boys and intervention girls hade the highest rates of smoking siblings while the controf boys also had the highest parental smoking rate. This could partly explain the apparently inconsisten effects of intervention. None the less, the regression analysis made allowance for the effect of parental andsibling smoking, and the effect of intervention was still found to differ significantly between the boys and girls.

Between 1980 and 1982 there was a decline in the presence of an antismoking norm among the children. This decline was greater among the intervention group children, which probably reflects a change in the children's friendship patterns. Whereas in 1980 , shortly after they entered secondary school, the children's friends were largely their peers from junior school, by 1982 they had established new friendships often with children from different junior schools, This meant that the strong antismoking norm of the children in the intervention group was weakened as they began to make friends with children who had received no health education and who reported a more prosmoking norm. The purpose of the My Body project was to "inoculate"? the children while in junior school against the social pressure to adopt smoking that they would experience after they entered secondary school. It seems to have worked for the boys.

Between 1980 and 1982 all the boys became less antismoking but they also became more aware of the 
Table 6 Relation between 1980 characteristics of the children and their uptake of smoking in the subsequent two years

\begin{tabular}{|c|c|c|c|c|c|}
\hline \multirow{2}{*}{$\begin{array}{l}1980 \text { characteristics } \\
\text { (11-12 year olds) }\end{array}$} & & \multicolumn{4}{|c|}{ Incidence of regular smoking (1980-2) } \\
\hline & & Boys & $(\mathrm{No})$ & Girls & $(N o)$ \\
\hline My Body project & $\begin{array}{l}\text { Participants } \\
\text { Non-participants }\end{array}$ & $\begin{array}{r}6 \% \\
11 \%\end{array}$ & $\begin{array}{r}(168) \\
(99)\end{array}$ & $\begin{array}{r}15 \% \\
7 \%\end{array}$ & $\begin{array}{r}(151) \\
(84)\end{array}$ \\
\hline Social class & $\begin{array}{l}\text { Non-manual } \\
\text { Manual }\end{array}$ & $\begin{array}{l}7 \% \\
8 \%\end{array}$ & $\begin{array}{r}(139) \\
(92)\end{array}$ & $\begin{array}{r}9 \% \\
13 \%\end{array}$ & $\begin{array}{r}(115) \\
(82)\end{array}$ \\
\hline Parental smoking behaviour & $\begin{array}{l}\text { Non-smokers } \\
\text { Smokers }\end{array}$ & $\begin{array}{l}9 \% \\
7 \%\end{array}$ & $\begin{array}{l}(140) \\
(125)\end{array}$ & $\begin{array}{l}12 \% \\
13 \%\end{array}$ & $\begin{array}{l}(116) \\
(117)\end{array}$ \\
\hline Sibling smoking behaviour & $\begin{array}{l}\text { Non-smokers } \\
\text { Smokers }\end{array}$ & $\begin{array}{r}7 \% \\
22 \%\end{array}$ & $\begin{array}{r}(237) \\
(23)\end{array}$ & $\begin{array}{r}12 \% \\
7 \%\end{array}$ & $\begin{array}{r}(218) \\
(15)\end{array}$ \\
\hline Children's smoking behaviour & $\begin{array}{l}\text { Non-smokers } \\
\text { Experimental smokers }\end{array}$ & $\begin{array}{r}5 \% \\
14 \%\end{array}$ & $\begin{array}{r}(177) \\
(90)\end{array}$ & $\begin{array}{r}8 \% \\
25 \%\end{array}$ & $\begin{array}{r}(170) \\
(65)\end{array}$ \\
\hline $\begin{array}{l}\text { Children's intention to } \\
\text { smoke when older }\end{array}$ & $\begin{array}{l}\text { Do not intend to smoke } \\
\text { Do intend to smoke }\end{array}$ & $\begin{array}{r}7 \% \\
25 \%\end{array}$ & $\begin{array}{r}(253) \\
(12)\end{array}$ & $\begin{array}{l}10 \% \\
33 \%\end{array}$ & $\begin{array}{r}(213) \\
(18)\end{array}$ \\
\hline Family problems & $\begin{array}{l}\text { Some } \\
\text { A lot }\end{array}$ & $\begin{array}{r}7 \% \\
13 \%\end{array}$ & $\begin{array}{r}(235) \\
(32)\end{array}$ & $\begin{array}{l}13 \% \\
11 \%\end{array}$ & $\begin{array}{r}(197) \\
(38)\end{array}$ \\
\hline Subjective norm & $\begin{array}{l}\text { Antismoking } \\
\text { Prosmoking }\end{array}$ & $\begin{array}{r}7 \% \\
15 \%\end{array}$ & $\begin{array}{r}(226) \\
(41)\end{array}$ & $\begin{array}{l}11 \% \\
15 \%\end{array}$ & $\begin{array}{r}(176) \\
(59)\end{array}$ \\
\hline Health hazards of smoking & $\begin{array}{l}\text { Aware } \\
\text { Unaware }\end{array}$ & $\begin{array}{l}7 \% \\
8 \%\end{array}$ & $\begin{array}{r}(85) \\
(182)\end{array}$ & $\begin{array}{l}17 \% \\
10 \%\end{array}$ & $\begin{array}{r}(90) \\
(145)\end{array}$ \\
\hline Diseases caused by smoking & $\begin{array}{l}\text { Able to identify } \\
\text { Unable to identify }\end{array}$ & $\begin{array}{l}5 \% \\
9 \%\end{array}$ & $\begin{array}{r}(82) \\
(185)\end{array}$ & $\begin{array}{l}11 \% \\
13 \%\end{array}$ & $\begin{array}{r}(80) \\
(155)\end{array}$ \\
\hline Attitude to smoking & $\begin{array}{l}\text { Antismoking } \\
\text { Prosmoking }\end{array}$ & $\begin{array}{l}8 \% \\
8 \%\end{array}$ & $\begin{array}{r}(214) \\
(53)\end{array}$ & $\begin{array}{l}11 \% \\
17 \%\end{array}$ & $\begin{array}{r}(187) \\
(48)\end{array}$ \\
\hline
\end{tabular}

health hazards of smoking. The headstart that the My Body programme had given the intervention boys in health awareness seems to have retarded the rate at which they adopted smoking during this vulnerable period.

In addition, the final longitudinal analysis showed that for boys the intention to adopt smoking expressed at 11-12 years had considerable value in predicting smoking behaviour two years later. Since fewer of the intervention group boys intended to smoke when older it seems that the My Body project had stunted any desire to adopt smoking which could have been cultivated after they entered secondary school. Thus it would seem that the My Body project was taught to the boys at the best age to have maximum impact in reducing the incidence of smoking. This did not seem to have been the case among the girls.

Although the intervention girls had a headstart in awareness of the health hazards of smoking, the control girls almost caught up with them subsequently, unlike with the boys where the difference was maintained. While the My Body programme gave the intervention girls a head start in health awareness it did not provide them with the basis for the growth of such knowledge which seems to be necessary to compete against the inducements to adopt smoking. It is possible that for girls, at least, early inoculation must be supplemented with constant reinforcement of the health awareness during this vulnerable period if the incentives to adopt smoking are to be combatted.

The girls' smoking/non-smoking career seems to start at a later stage than the boys'. Thus the My Body project was possibly taught to the girls at too early a stage such that while its content may have been accepted it did not provide the basis for the further development of health awareness. Among the girls early awareness of the health hazards of smoking seemed to have actually raised their risk of smoking. This knowledge base seemed to leave them more vulnerable when their friendship patterns changed and the antismoking norm declined. It would seem that the My Body programme was taught to the girls before the desire to smoke had even begun to germinate.

The My Body programme also seemed to have had a small indirect effect on the parents and siblings of the intervention group, especially of the intervention boys. This effect may possibly have been created by the intervention children urging their parents and siblings to quit smoking. ${ }^{8}$ 
In conclusion, health education is still at an early stage and evaluation of programmes, such as that reported above, is essential for its development. Our findings suggest that future evaluation should pay especial attention to the differential impact of programmes on boys and girls and on different age groups.

We are grateful to the teachers and pupils in the schools who participated in this study for their co-operation and to Professor WW Holland for his continuing support.

Financial support was provided by the Health Education Council and by the Department of Health and Social Security, London.

\section{References}

${ }^{1}$ Royal College of Physicians. Health or smoking? London: Pitman, 1983.

${ }^{2}$ Milne A, Marshall-Mies J, Colmen JC. A study of the impact of the school health curriculum project on knowledge, attitudes and behaviour of teenage students. Washington: Education and Public Affairs, 1975.

${ }^{3}$ Wilcox B, Engel E, Reid D. Smoking education in children: UK trial of an international project. Int $J$ Health Educ 1978; 21: 236-44.

${ }^{4}$ Murray M, Swan AV, Johnson MRD, Enock D, Banks MH, Reid DJ. The effectiveness of the My Body school health education project. Health Education Journal 1982; 41: 126-30.

${ }^{5}$ Baker RT, Nelder JA. The GLIM manual for system 3. Oxford: Numerical Alogrithms Group, 1978.

${ }^{6}$ Armitage P. Statistical methods in medical research. Oxford: Blackwell Scientific Publications, 1971.

${ }^{7}$ Evans RI. Smoking in children: developing a social psychological strategy of deterence. Journal of Preventive Medicine 1976; 5: 122-7.

${ }^{8}$ Wilcox B, Gillies P, Wilcox S, Reid D. Do children influence their parents' smoking? Health Education Journal 1980; 40: 5-10. 